\title{
Downsizing and the Survivor Syndrome: The South African Case
}

\section{Leopold Vermeulen}

Department of Human Resources Management, University of Pretoria

\section{Retha Wiesner}

Department of Human Resource Management and Employment Relations, University of Southern Queensland

\section{ABSTRACT}

The purpose of this study was to obtain empirical data about the effect of workforce reduction on "survivors" in the public $(n=158)$ and private $(n=71)$ sectors in South Africa. Analysis of the effects of workforce reduction indicated that downsizing affected the survivors negatively. Employee morale, staff commitment and motivation plummeted, while job dissatisfaction and concern about job security increased conspicuously. It was found that the negative effects were more prevalent in the public than the private sector. Depth and frequency of downsizing seem not to intensify the survivor syndrome.

JEL M12

\section{INTRODUCTION}

In the recent past, say since 1994, South African organisations have had to cope with socio-political changes, new governmental regulations, a re-introduction to global markets and pressure on costs and margins as well as the demands of affirmative action. In addition, specific South African business trends such as unbundling, industry deregulation and the privatisation of public sector companies created new competitive forces in certain industries which necessitated organisational change.

An increasingly persuasive response to this experience (to change) was to engage in some form of organisational restructuring, which included downsizing, right-sizing and re-engineering. These concepts all share one common assumption, namely workforce reduction and job elimination.

South African companies in the private sector first showed signs of staff reduction during the course of the eighties. Since 1990 the number employed in the industrial sector have continued to diminish with an overall low in 1996. An 
indication of the total number of job cuts since 1991 is given in Table 1 and is reflected in Figure 1.

Table 1 Cut in staff of the top 100 companies in the industrial sector listed on the JSE

\begin{tabular}{|l|r|r|r|r|r|r|}
\hline & \multicolumn{1}{|c|}{1991} & \multicolumn{1}{|c|}{1992} & \multicolumn{1}{|c|}{1993} & \multicolumn{1}{c|}{1994} & \multicolumn{1}{c|}{1995} & \multicolumn{1}{c|}{1996} \\
\hline $\begin{array}{l}\text { Companies } \\
\text { increased staff }\end{array}$ & 37 & 37 & 33 & 43 & 55 & 48 \\
\hline $\begin{array}{l}\text { New appointments } \\
\text { Companies } \\
\text { decreased staff }\end{array}$ & 25426 & 82673 & 52809 & 39828 & 40416 & 43457 \\
\hline Staff reduction & -83656 & -81532 & -82798 & -164265 & -39847 & -64192 \\
\hline Jobs Gained/Lost & -64230 & +1141 & -29989 & -124437 & +569 & -20735 \\
\hline
\end{tabular}

Source: Adapted from Supplement to the Financial Mail (1990/97)

The labour utilisation data of the major employers in South Africa, reflected that the percentage of companies that downsized their staff reached its *highest level in 1993 with the employment cycle at its lowest point in 1994. After a period of growth in 1995, private sector employment started dropping in the third quarter per cent of 1995 , with declines of $5.8 \%, 3.6 \%$ and $2.8 \%$ in the first threequarters of 1996 (see Figure 1).

Figure 1 Employment trends in South Africa: 1991-1996 (Index $1991=100$ )

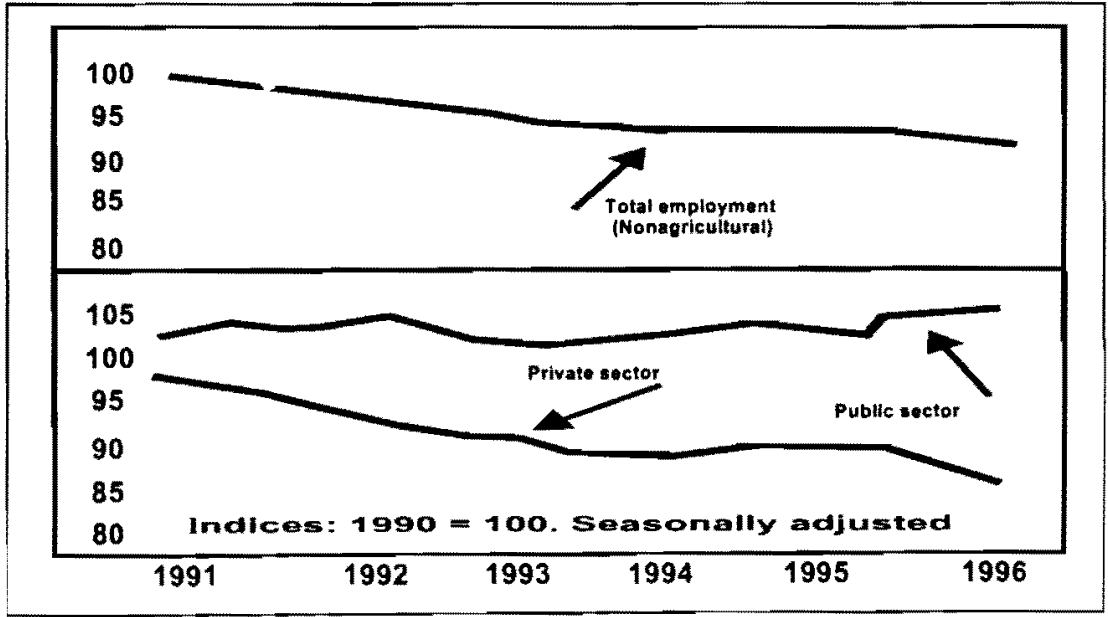

Source: SA Reserve Bank 
However, in 1996 (at the time of the national survey) there was no sign of the process letting up - $44 \%$ of South African managers expected the restructuring cycle to continue over the next two years (1997/98). The Reserve Bank figures showed that 104000 jobs were lost in the first nine months of 1997 and in its most recent survey Statistics SA reported that 186000 jobs were lost during 1998 (Williams, 1999: 1).

In South Africa many public sector corporations, city councils and even the public service have undergone restructuring to adjust to the imperatives of the new South Africa. Most of the larger utilities have cut their payrolls since June 1994. Transnet, one of the largest transport public sector companies for example, downsized 27059 workers from 1994 up to 1996 (Segal, 1997: 351-2).

Another major emphasis of government is the "right-sizing" of the public service. 300000 public service jobs had to be shed in three years $(1996 / 7 / 8)$. To this end 18184 jobs were lost during 1996/97 (Swart, 1998: 8).

Based on the above summary of trends in downsizing and job elimination in South Africa, the question arose as to what the effects of downsizing are on the survivors. Much of the research in this area is organised around the notion of the "survivor syndrome" (Littler, Bramble \& Dunford, 1995; Littler, Dunford, Bramble \& Hede, 1996; Vermeulen, Wiesner \& Littler, 1999). In this paper the focus is on the effects of workforce reduction on the survivors in the private and public sectors in South Africa.

The major research questions we address in this article, are as follows:

- What is the impact of downsizing on South African employees in the private and public sectors?

- What factors intensify and modify the survivor syndrome?

\section{Downsizing survivor syndrome}

The toll of job elimination and downsizing on human resources in a company is often extremely negative. Survivors of workforce reductions experience a wide range of emotions - grief and shock at the loss of their colleagues, guilt from feeling responsible for everyone's suffering, uncertainty about their competence and job identity, relief at being spared, fear that at the next round of cut-backs they may not be so fortunate and anger that the company they trusted has changed the "rules of the game" (NPI, 1996: 20; Stevenson, 1998: 42).

Downsizing frequently results in the so-called "survivor syndrome". This syndrome is apparent among both lower-level and managerial staff, with the 
latter in particular undergoing a commitment crisis. Employee loyalty and motivation is jeopardised during downsizing, particularly in those companies that fail to share information both during and after the downsizing (Brockner et al., 1987; Brockner, 1988; Brockner, 1992). Management experiences diminishing expectations regarding their chances for advancement, leading to a decline in commitment to the company and increased staff turnover. Managers who find that the organisation's vision, values and direction are no longer compatible to their own beliefs, have their expectations and dreams shattered. They may work their way out of this predicament by creating alternative options for themselves within or outside the organisation (Stevenson, 1998: 42). As a result, downsizing fundamentally alters the terms of the psychological contract that binds workers to organisations. This has a wide impact on the companies concerned as the resulting low morale and lack of trust have ripple effects on virtually every people-related aspect of business activity (Cascio 1993: 101-3).

Unless a company is willing to undertake the hard but necessary work of developing a new contract to replace the old one, employees will just feel betrayed and this shows in many ways including lost loyalty, poor morale, health problems and reduced customer service (Challenger in Laabs, 1999: 6).

To summarise, survivor syndrome involves a decline in organisational commitment, a loss of morale, a lack of trust and a focus on personal security rather than any corporate goals. These may have long-term outcomes in relation to performance, innovative capacity and organisational learning in South Africa (Roos, 1993; Louw, 1995; Thomas, 1996; Stevenson, 1998).

\section{METHOD AND RESEARCH PROCEDURE}

The primary purpose of the investigation was to obtain empirical data with regard to the effect of downsizing on employees in South Africa. Littler's Organisational Change Survey Questionnaire was used in a survey of employees' reactions on downsizing in the private and public sectors. The questionnaire was developed and standardised by Littler et al. (1995) to measure downsizing and delayering in Australia and New Zealand. The questionnaire consists of five sections. In this study the data of the following three sections were used, i.e. the organisation, the effect of workforce reduction and the demographics of the respondents.

Despite the widespread use of the term "survivor syndrome", it has not been adequately or operationally defined. Littler et al. (1996) defined it in terms of six key Human Resource Management variables i.e. 
- Job dissatisfaction;

- Staff motivation;

- Staff commitment;

- Morale among staff;

- Concern about job security;

- Perceived promotional opportunities. (decreased levels) (increased levels)

(decreased levels)

(decreased levels)

(decreased levels)

(increased levels)

These factors were used consistently across the survey questions in relation to the workforce in general. Other factors could have been incorporated, such as stress levels, but Littler et al. (1996) wished to keep the construct as simple as possible to avoid problems of weak convergent validity. The works of Brockner et al. (1985), Greenhalgh \& Jick (1989), and Cameron et al. (1993) suggest that the above factors are common across a range of studies and should have convergent validity.

In defining the limits of this study, it should be noted that the unit of analysis was the organisation, not the individual employee. We asked HR managers about their perceptions of a variety of employee attitudinal factors including morale, staff commitment, perceived promotional opportunities, motivation, job satisfaction and concern about job security. Respondents were asked to assess these items in relation to three categories (increased, decreased and unchanged). It is reasonable to assume that if any bias occurred the HR managers would under-report employee downturns in morale and commitment. The questionnaire was administered in South Africa during May/June 1996.

\section{STATISTICAL ANALYSIS}

The ordinale scale was used as the level of measurement. For the purpose of this paper, descriptive and non-parametric statistics were employed in order to demonstrate comparative trends in the data.

To determine differences between the private and public sectors on the effects of downsizing on key human resource variables, the Mann-Whitney U-test was used. To determine the effect of depth and frequency of downsizing in respect of the survivor syndrome the Kruskal Wallis rank order analysis of variance was used. The Spearman rank order correlation coefficient was calculated to determine whether depth and frequency of downsizing are related to the intensity of the survivor syndrome. The SPSS for Windows Statistical Package, Release 6.1, was applied for all statistical procedures.

It was reasoned that staff working in the human resources area of organisations would have a perspective on restructuring, which is reasonably well-informed 
and is more detached than line managers who may be directly affected by such organisational change. The sampling frame was derived from the professional register obtained from the South African Board for Personnel Practice. One thousand two hundred names were randomly picked from the register, and the sample represents more organisations than those noted on the Stock Exchange. A questionnaire, accompanied with a covering letter, was mailed to each member of the sample. A reminder and an additional copy of the questionnaire were sent to approximately 500 respondents six weeks after the initial mailing. Of the questionnaires originally sent out, 421 responses were received. This represented a rate of $35.08 \%$. Of the 421 questionnaires sent back, 17 were spoiled and 22 returned unopened or unanswered.

The number of usable questionnaires received from each industrial sector for South Africa is shown in Table 2.

Table 2 Respondent industry profile

\begin{tabular}{|l|c|c|}
\hline \multicolumn{1}{|c|}{ Industrial Sector } & $\begin{array}{c}\text { Frequency } \\
\text { (n) }\end{array}$ & $\begin{array}{c}\text { Percentage } \\
(\%)\end{array}$ \\
\hline Agriculture & 17 & 4.5 \\
\hline Mining & 45 & 11.8 \\
\hline Manufacturing & 87 & 22.8 \\
\hline Electricity and Gas & 27 & 7.1 \\
\hline Construction & 8 & 2.1 \\
\hline Trade and catering & 31 & 8.1 \\
\hline Transport, Storage and Communication & 33 & 8.6 \\
\hline Finance & 50 & 13.1 \\
\hline Public Adnuinistration & 25 & 6.5 \\
\hline Community service & 48 & 12.6 \\
\hline Other & 11 & 2.80 \\
\hline Total & 382 & 100 \\
\hline
\end{tabular}

The distribution of the responding organisations in terms of sector and number of employees is provided in Tabel 3. 
Table 3 Characteristics of participating organisations

\begin{tabular}{|l|c|c|}
\hline $\begin{array}{c}\text { Organisational variables } \\
\text { Organisational Sector }\end{array}$ & $\begin{array}{c}\text { Frequency } \\
\mathbf{n}\end{array}$ & $\begin{array}{c}\text { Percentage } \\
\%\end{array}$ \\
\hline Private Sector & 266 & 69.6 \\
\hline Public Sector & 115 & 30.4 \\
\hline Total & 381 & 100 \\
\hline Number of Employees & $\mathbf{n}$ & $\%$ \\
\hline $0-500$ & 84 & 22.0 \\
\hline $501-1000$ & 55 & 14.4 \\
\hline Over a 1000 & 243 & 63.6 \\
\hline Total & 382 & 100 \\
\hline
\end{tabular}

\section{RESULTS}

\section{Comparative trends}

Of the 382 organisations in South Africa participating in this study, 60.4\% indicated that they had been involved in downsizing during 1994 to 1996. Downsizing were more prevalent in the public sector $(62.8 \%)$ than in the private sector $(59.6 \%)$.

Table 4 Downsizing trends in South Africa: 1994 - 1996

\begin{tabular}{|l|c|c|c|}
\hline & Country & \multicolumn{2}{|c|}{ Sector } \\
\hline Downsized & $\begin{array}{c}\text { South Africa } \\
\mathrm{n}=381\end{array}$ & $\begin{array}{c}\text { Private } \\
\mathrm{n}=266\end{array}$ & $\begin{array}{c}\text { Public } \\
\mathrm{n}=155\end{array}$ \\
\hline Yes & $60.4 \%$ & $59.6 \%$ & $62.8 \%$ \\
\hline Not at all & $39.6 \%$ & $40.4 \%$ & $37.2 \%$ \\
\hline $\begin{array}{l}\text { Depth of workforce } \\
\text { reduction }\end{array}$ & $\begin{array}{c}\text { Downsizers } \\
\mathrm{n}=229\end{array}$ & $\begin{array}{c}\text { Downsizers } \\
\mathrm{n}=158\end{array}$ & $\begin{array}{c}\text { Downsizers } \\
\mathrm{n}=71\end{array}$ \\
\hline $1-10 \%$ & $59.8 \%$ & $57.0 \%$ & $66.1 \%$ \\
\hline $11-20 \%$ & $24.5 \%$ & $27.2 \%$ & $18.3 \%$ \\
\hline $21-30 \%$ & $7.4 \%$ & $7.6 \%$ & $7.1 \%$ \\
\hline More than 30\% & $8.3 \%$ & $8.2 \%$ & $8.5 \%$ \\
\hline $\begin{array}{l}\text { Frequency of workforce } \\
\text { reduction }\end{array}$ & & & $3 \%$ \\
\hline Once & $42.7 \%$ & $39.3 \%$ & $52.2 \%$ \\
\hline Twice & $16.8 \%$ & $15.2 \%$ & $19.7 \%$ \\
\hline 3 or more times & $40.5 \%$ & $45.5 \%$ & $28.1 \%$ \\
\hline
\end{tabular}


The data in Table 4 show that the majority (59.8\%) of the South African organisations had a workforce reduction of between one and ten per cent. Fifty six $(24.5 \%)$ of the employers reduced their workforce between $11 \%$ and $20 \%$ and seventeen (7.4\%) reduced their workforce between $21 \%$ and $30 \%$. Only nineteen organisations reduced their workforce by more than $30 \%$.

Forty three per cent of the South African organisations downsized once, $16.8 \%$ downsized twice and $40.5 \%$ were engaged in workforce reduction three times or more. The data indicated that only $28.1 \%$ of the organisations in the public sector had downsized three or more times over the two year period 1994/1996. This figure is significantly lower than the private sector which had downsized three or more times in $45.5 \%$ of cases.

\section{SURVIVOR SYNDROME}

The downsizing survivor syndrome is normally defined as the set of emotions and behaviours exhibited by employees who remain in the organisation after the process of downsizing is completed. Table 5 summarise the comparative effects of downsizing on morale, staff commitment, perceived promotion opportunities, motivation, job dissatisfaction and concern about job security.

Table 5 The effects of workforce reduction: downsizing syndrome

\begin{tabular}{|c|c|c|c|c|c|c|}
\hline \multirow{3}{*}{\begin{tabular}{|l} 
OUTCOME \\
HRM variables
\end{tabular}} & \multirow{2}{*}{\multicolumn{2}{|c|}{$\begin{array}{c}\text { COUNTRY } \\
\text { South Africa } \\
n=229\end{array}$}} & \multicolumn{4}{|c|}{ SECTOR } \\
\hline & & & \multicolumn{2}{|c|}{$\begin{array}{l}\text { Private } \\
\mathrm{n}=158\end{array}$} & \multicolumn{2}{|c|}{$\begin{array}{c}\text { Public } \\
\mathrm{n}=71\end{array}$} \\
\hline & Inc & Dec & Inc & Dec & Inc & Dec \\
\hline Morale & $9.2 \%$ & $75.4 \%$ & $12.8 \%$ & $70.5 \%$ & $11.3 \%$ & $87.3 \%$ \\
\hline Staff commitment & $13.8 \%$ & $68.8 \%$ & $18.4 \%$ & $59.9 \%$ & $2.8 \%$ & $88.7 \%$ \\
\hline $\begin{array}{l}\text { Perceived promotional } \\
\text { opportunities }\end{array}$ & $32.5 \%$ & $43.2 \%$ & $40.6 \%$ & $32.9 \%$ & $23.9 \%$ & $64.8 \%$ \\
\hline Motivation & $12.6 \%$ & $70 \%$ & $17.2 \%$ & $61.6 \%$ & $2.8 \%$ & $88.7 \%$ \\
\hline Job dissatisfaction & $48.6 \%$ & $20.8 \%$ & $43.8 \%$ & $21.9 \%$ & $59.4 \%$ & $18.8 \%$ \\
\hline $\begin{array}{l}\text { Concern about job } \\
\text { security }\end{array}$ & $80 \%$ & $7.6 \%$ & $77.8 \%$ & $6.5 \%$ & $84.5 \%$ & $9.9 \%$ \\
\hline
\end{tabular}

According to Table 5, employee morale fell in $75.4 \%$ of cases, commitment decreased in $68.8 \%$ of cases and motivation decreased in $70 \%$ of cases, while concern about job security increased in $80 \%$ of cases.

A comparison between the perceived effects of downsizing by the private and 
public sectors respondents disclosed a similar pattern. However, the survey results showed that the public sector was more affected by the negative effects of downsizing. Of the cases surveyed, employee morale decreased by $87.3 \%$, staff commitment decreased by $88.7 \%$, perceived promotional opportunities decreased by $64.8 \%$ and motivation decreased by $88.7 \%$ of cases. Concem about job security increased in an overwhelming $84.5 \%$ of cases.

The Mann-Whitney U-test confirmed significant differences $(p<0.01)$ between the public and private sectors in relation to four of the survivor syndrome variables i.e. morale, staff commitment, perceived promotional opportunities and motivation.

Table 6 Differences between the private and public sectors in respect of the effects of downsizing on the survivors

\begin{tabular}{|l|c|c|c|c|}
\hline HRM Variables & $\begin{array}{c}\text { Private } \\
\text { n=156 }\end{array}$ & $\begin{array}{c}\text { Public } \\
\mathbf{n = 7 1}\end{array}$ & & \\
\hline & Mean Rank & Mean Rank & U-Value & 2-Tailed \\
\hline Morale among staff & 120.62 & 99.45 & 4505.0 & $0.0028^{*}$ \\
\hline Staff commitment & 122.84 & 88.80 & 3749.0 & $0.0000^{*}$ \\
\hline $\begin{array}{l}\text { Perceived promotional } \\
\text { opportunities }\end{array}$ & 124.02 & 90.53 & 3871.5 & $0.0001^{*}$ \\
\hline Staff motivation & 121.67 & 89.87 & 3825.0 & $0.0000^{*}$ \\
\hline Job dissatisfaction & 103.01 & 118.55 & 4309.0 & 0.0635 \\
\hline $\begin{array}{l}\text { Concern about job } \\
\text { security }\end{array}$ & 110.53 & 116.75 & 5130.0 & 0.3386 \\
\hline
\end{tabular}

${ }^{*} \mathrm{p}<0.01 \%$

An analysis of Tables 5 and 6 confirms that workforce reduction has a negative effects on the survivors and that downsizing leaves people bruised and far less committed. It also destroys employee trust in the organisation.

\section{DISCUSSION}

In some ways these results are not surprising, because added into the mix of downsizing and restructuring in South Africa, there was the change in government, the loss of political power by whites, the end of apartheid and the introduction of affirmative action. The ratios of $4: 3$ in promotion opportunities in the private sector and 2:6 in the public sector were rather surprising. These results may be due to the policy of affirmative action, which has become a mainstream labour practice in the public sector since 1994 . 
Due to affirmative action, many competent black managers in the public sector find themselves in an enviable position with regard to promotion. Many white managers find themselves on a career plateau with restricted career opportunities. The following written comment by a white male respondent summarises the perception: "Affirmative action has resulted in many people skipping the normal promotional steps. This has led to a decreased perception of promotional opportunities by especially white people, and inefficiency caused by delays, while they (the new managers) learn the job and often learn by their mistakes. The latter has led to a high level of frustration on the part of many colleagues. Stress levels have increased enormously".

However, affirmative action and empowerment of at least some black people do not explain the South African picture. The South African downsizing story cuts across both sectors. The figures in Table 5 reflect a scene of civil servants in crisis as restructuring erodes old securities. South African insecurity indigestion has not been assisted by the extent and depth of the public sector restructuring. 300000 public service jobs are to be shed in three years. Headlines like "Public servants in panic over an uncertain future" (Pretoria News, 1996: 19) circulate regularly, fuelled by statements from politicians like "no public servant should feel ensured of a job in the public service in three years time!" (Pretoria News, 1992: 19).

Though there are idiosyncratic factors (such as the affirmation action policy effects), the data suggests a consistent pattern which confirm the negative effects of downsizing on worker behaviour. However, literature (Litter C R et al,, 1996) suggests that the intensity of the survivor syndrome may be influenced by the depth, frequency and recency of downsizing.

For the second objective of this paper, we try to identify the factors that influence the survivor syndrome outcomes. The question we try to answer is: what factors intensify and modify the survivor syndrome?

\section{Depth of downsizing}

The downsizing literature suggests that depth of downsizing ( $10 \%$ versus $20 \%$ for example) makes a difference to the HRM outcomes. For example, Brockner (1988: 230-1) found that lay-off severity was negatively associated with organisational commitment. This notion has been expanded to a more complex explanation by some researchers. However, no significant $(\mathrm{p}>0.05)$ correlation (rho) was found between the depth of cutting and the six key HRM variables which represent the survivor syndrome (Table 7 ). 
Table 7 Spearman rank order correlation between depth and frequency of workforce reduction and the effect of downsizing on the survivors $(n=226)$

\begin{tabular}{|l|c|c|}
\hline \multicolumn{1}{|c|}{$\begin{array}{c}\text { Effect of downsizing } \\
\text { (HRM variables) }\end{array}$} & \multicolumn{2}{c|}{ Workforce reduction } \\
\hline & Depth & Frequency \\
\cline { 2 - 3 } & rho & rho \\
\hline Morale among staff & -0.052 & -0.042 \\
\hline Staff commitment & -0.009 & -0.031 \\
\hline Perceived promotional opportunities & -0.126 & -0.082 \\
\hline Staff motivation & -0.028 & -0.052 \\
\hline Job dissatisfaction & -0.009 & 0.026 \\
\hline Concern about job security & -0.135 & 0.002 \\
\hline
\end{tabular}

$p>0.05$

In order to determine whether depth of workforce reduction (1-10\% to more than $30 \%$ ) makes a difference to the HRM variables, the Kruskal Wallis rank order analysis of variance was executed in respect of all the South African data as well as for the public and private sectors data. The analysis yields no statistically significant difference $(p>0.05)$ between depth of workforce reduction and the intensity of the survivor syndrome. The depth of cutting seems to have no effect on the survivor syndrome outcomes (Table 8).

Table 8 Kruskal Wallis rank order analysis of variance for depth in workforce reduction in respect of the effect of downsizing on the survivors $(n=226)$

\begin{tabular}{|c|c|c|c|c|c|c|}
\hline Effect of down- & \multicolumn{4}{|c|}{ Depth of workforce reduction } & \multirow{2}{*}{$\begin{array}{c}\text { Chi- } \\
\text { square }\end{array}$} & \multirow{2}{*}{$\begin{array}{c}\text { Signifi- } \\
\text { cant }\end{array}$} \\
\hline HRM Variables & $\begin{array}{l}1-10 \% \\
n=135\end{array}$ & $\begin{array}{c}11-20 \% \\
n=56\end{array}$ & $\begin{array}{c}21-30 \% \\
n=16\end{array}$ & $\begin{array}{l}30 \%> \\
n=19\end{array}$ & & \\
\hline & $x$ rank & $\mathrm{x}$ rank & $\mathrm{x}$ rank & $\mathrm{x}$ rank & & \\
\hline Morale among staff & 116.13 & 107.25 & 108.66 & 117.32 & 1.5686 & 0.6665 \\
\hline Staff commitment & 111.99 & 110.46 & 111.31 & 111.34 & 0.0342 & 0.9983 \\
\hline $\begin{array}{l}\text { Perceived promotion } \\
\text { opportunities }\end{array}$ & 118.74 & 108.56 & 100.72 & 95.95 & 3.6758 & 0.2987 \\
\hline Staff motivation & 112.69 & 106.21 & 108.13 & 115.42 & 0.8049 & 0.8483 \\
\hline Jab dissatisfaction & 112.71 & 105.96 & 102.43 & 78.67 & 5.8274 & 0.1203 \\
\hline $\begin{array}{l}\text { Concern about job } \\
\text { security }\end{array}$ & 111.73 & 115.30 & 113.78 & 102.66 & 1.1446 & 0.7663 \\
\hline
\end{tabular}

$p>0.05$ 


\section{Frequency}

Another factor which may influence the survivor syndrome is the frequency of downsizing. As we mentioned in the introduction, $40.2 \%$ of the South African organisations had downsized three or more times over the two year period 19941996. In the private sector $45.5 \%$ of the organisations have downsized three or more times over the two year period. $52 \%$ of downsizing organisations in the public sector had downsized once and only $28.1 \%$ downsized three or more times over the two year period. The frequency of downsizing has been less in the public sector than the private sector and this may be due to the fact that the restructuring cycle is still relatively new in the public sector.

According to Jeffrey Pfeffer, a professor of organisation behaviour at the Stanford Graduate School of Business, case studies show that repeated waves of downsizing are crushing to morale, reduce credibility and trust in management and make high performance work practices difficult, if not impossible, to implement (Laabs, 1999: 10). This view is not supported by Louw (1995). He found that organisations that had downsized before, and then downsized for a second time, experienced less of a negative impact on job focus than they did the first time round.

The results of our study also revealed no empirical evidence of a relationship (rho) between frequency of downsizing and the six key HRM variables which constitute the survivor syndrome (Table 7). The Kruskal Wallis rank order analysis of variance also yields no statistically significant difference $(p>0.05)$ between the frequency of workforce reduction and the survivor syndrome. The frequency of cutting jobs also seems to have no significant impact on the intensity of the survivor syndrome (Table 9).

Table 9 Kruskal Wallis rank order analysis of variance for times engage in workforce reduction in respect of the effect of downsizing on the survivors $(n=226)$

\begin{tabular}{|c|c|c|c|c|c|}
\hline Effect of downsizing & \multicolumn{3}{|c|}{$\begin{array}{l}\text { Frequency of workforce } \\
\text { reduction }\end{array}$} & $\begin{array}{l}\text { Chi- } \\
\text { square }\end{array}$ & $\begin{array}{l}\text { Signifi- } \\
\text { cant }\end{array}$ \\
\hline HRM variables & $\begin{array}{c}\text { Once } \\
\mathbf{n}=95 \\
\mathrm{x} \text { rank }\end{array}$ & $\begin{array}{c}\text { Twice } \\
\mathrm{n}=39 \\
\mathrm{x} \text { rank }\end{array}$ & $\begin{array}{c}\text { Three+ } \\
n=92 \\
x \text { rank }\end{array}$ & & \\
\hline Morale among staff & 116.52 & 112.64 & 111.95 & 0.4369 & 0.8038 \\
\hline Staff commitment & 113.40 & 113.76 & 109.81 & 0.2652 & 0.8758 \\
\hline $\begin{array}{l}\text { Perceived promotion } \\
\text { opportunities }\end{array}$ & 120.57 & 104.29 & 109.81 & 2.5205 & 0.2836 \\
\hline
\end{tabular}


Table 9 continued

\begin{tabular}{|l|c|c|c|c|c|}
\hline \multicolumn{1}{|c|}{ Effect of downsizing } & \multicolumn{3}{|c|}{$\begin{array}{c}\text { Frequency of workforce } \\
\text { reduction }\end{array}$} & $\begin{array}{c}\text { Chi- } \\
\text { square }\end{array}$ & $\begin{array}{c}\text { Signifi- } \\
\text { cant }\end{array}$ \\
\hline Staff motivation & 114.55 & 110.49 & 108.67 & 0.6076 & 0.7380 \\
\hline Job dissatisfaction & 104.67 & 117.19 & 107.75 & 1.2418 & 0.5375 \\
\hline $\begin{array}{l}\text { Concern about job } \\
\text { security }\end{array}$ & 110.82 & 120.20 & 111.03 & 1.3257 & 0.5154 \\
\hline
\end{tabular}

$\mathrm{p}>0.05$

\section{Recency of downsizing}

The third possible factor that may influences the survivor syndrome outcomes is recency of downsizing. The recency argument has not been fully articulated in the literature, with the possible exception of the "grief model" applied to organisational change. Downsizing and restructuring cause considerable problems at both a personal and structural level according to Stevenson (1998). The results of job loss on displaced people have been studied by psychologists for many years and findings show indisputably that redundancy has traumatic effects on people who lose their jobs. Those who have to carry out the task of job termination and those who stay behind in the organisations are similarly affected. A form of organisational trauma is experienced which impacts on productivity and profitability. However, over time the situation "cools down", people adapt and the "grief" problems are finally resolved by acceptance. Many people will leave the organisation including those who are most dissatisfied (Stevenson, 1998: 42).

The public sector only started extensive downsizing and restructuring since 1994, althougn some restructuring efforts date back to the early nineties. Our survey results indicate that survivor syndrome outcomes are extremely negative in the public sector (see Table 5). The negative impact of downsizing was still fresh in respondents' minds at the time of the survey and it is obvious that the situation had not "cooled down" yet. People have not adapted and the "grief" problems have not been resolved to a final stage of acceptance.

The respondents in the private sector have gone through downsizing much earlier and the situation seemed to indicate that the effect of the downsizing was not as intense as in the case of the public sector. These results imply that the recency of downsizing may influence the intensity of the survivor syndrome. Further longitudinal research is needed to confirm this view. 


\section{CONCLUSIONS}

We aimed to investigate the impact of downsizing on survivors. In this paper we have presented some of the initial results. It is evident from the results that the impact of downsizing has hit South African employees hard.

The results of the study confirm previous findings on the "survivor syndrome" (Brockner et al., 1985; Brockner et al, 1987; Brockner, 1988; Louw, 1995; Littler et al., 1996). Although in the South African environment other factors such as wide-spread socio-political changes and policies of Affirmative Action could have impacted on the negative outcomes, the data suggest a consistent pattern confirming the negative Human Resource effects of downsizing.

Downsizing is not a temporarily phenomenon that will soon disappear. Until recently, few voices have been raised against downsizing as a corporate strategy. However, as disenchantment about downsizing as a strategy has spread in the USA, it has been taken up as the restructuring strategy in many other economies. The paradox is that many U.S. firms now express misgivings about the principles of downsizing. It partly relates to the widespread phenomenon of survivor syndrome in the United States. Such a phenomenon implies that the objectives related to downsizing and organisational restructuring are often contradictory (Laabs, 1999: 1-10). Downsizing as a stand-alone strategy can minimise or negate any productivity improvements sought from a leaner workforce and job redesign.

\section{ENDNOTE}

This paper is part of a broader project on organisationa1 restructuring, downsizing, delayering and management labour markets co-ordinated by Professor Craig R. Littler in conjunction with Dr. Retha Wiesner (University of Southern Queensland), Professor Richard Dunford (Victoria University of Wellington), Dr. Tom Bramble (University of Queensland), and Professor Leo Vermeulen (University of Pretoria).

The authors would like to thank the National Research Foundation (NRF) for their financial assistance towards this research. Opinions expressed and conclusions arrived at are those of the authors, and are not necessarily to be attributed to the NRF. 


\section{REFERENCES}

1 BROCKNER, J. (1988) "The Effects of Work Layoffs on Survivors: Self-Esteem and Survivor Guilt: Research Theory and Practice", Research in Organisational Behaviour, 10: 213-55.

2 BROCKNER, J. (1992) "Managing the Effects of Layoffs on Survivors", California Management Review, 34(2): 9-28.

3 BROCKNER, J., DAVEY, J. and CARTER, C. (1985) "Layoffs, SelfEsteem and Survivor Guilt: Motivational, Affective, and Attitudinal Consequences", Organizational Behaviour and Human Decision Processes, 16: 229-44.

4 BROCKNER, J.; GROVER, S.; REED, T.; DEWITT, R. and O'MALLEY, M. (1987) "Survivors' Reactions to Layoffs: We Get By With a Little Help From Our Friends", Administrative Science Quarterly, 32: 526-41.

5 BROCKNER, J.; GROVER, S. and BLONDER, M. (1988) "Predictors of Survivors' Job Involvement Following Layoffs: A Field Study", Journal of Applied Psychology, 73(3): 436-42.

6 CAMERON, K.S.; FREEMAN, S.J. and MISHRA, A.K. (1993) "Downsizing and Redesigning Organisations" in G.P. Huber \& W.H. Glick (eds.) Organisational Change and Redesign, Oxford University Press, New York: 19-65.

7 CASCIO, W.F. (1993) "Downsizing: What Do We Know? What Have We Leamed?", Academy of Management Executive, 7(1): 95-104.

8 FINANCIAL MAIL (1992) "Job Cuts Mounting at Increasing Rate", Supplement to the Financial Mail: June: 171-6.

9 FINANCIAL MAIL (1993) "Little Relief Yet From the Jobs Axe", Supplement to the Financial Mail, June: 171-4.

10 FINANCIAL MAIL (1994) "Accent Stays on Cutting the Payrolls", Supplement to the Financial Mail, June: 210-14.

11 FINANCIAL MAIL (I995) "Jobs and Productivity", Supplement to the Financial Mail, June: 218-22.

12 FINANCIAL MAIL (1996) "Most Still Keeping a Tight Clamp on Payrolls", Supplement to the Financial Mail, June: 247-51.

13 FINANCIAL MAIL (1997) "Employment Statistics Give Little Hope", Supplement to the Financial Mail, June: 319-25.

14 FINANCIAL MAIL (1998) "Unemployment Figures Paint a Gloomy Picture", Supplement to the Financial Mail, June: 322-8.

15 GREENHALGH, L. and JICK, T.D. (1998) "Survivor Sense-Making and Reactions to Organizational Decline: Effects of Individual Differences", Management Communication Quarterly, 2(3): 305-27.

16 LAABS, J. (1999) "Has Downsizing Missed its Mark?", Internet http:/ www.workforceonline.com/cgi-bin/w ...iew\&dretry=downsizing\& 
filename $=3256 \mathrm{htm}$.

17 LITTLER, C.R.; BRAMBLE, T. and DUNFORD, R. (1995) "National Surveys of Organisational Restructuring in Australia and New Zealand: An Analysis", USO Working Report.

18 LITTLER, C.R.; DUNFORD, R.; BRAMBLE, T. and HEDE, A. (1996) "The Dynamics of Downsizing in Australia and New Zealand", Asia Pacific Journal of Human Resources, 31(1): 65-79.

19 LITTLER, C.R. and WIESNER, R. (1996) "Restructuring in South Africa - Mandela's Managers in Crisis", Financial Review, Opinion page leading article, 6 December.

20 LOUW, H.P. (1995) "Management Perceptions of Employee Morale after Downsizing", Unpublished Masters dissertation, University of Witwatersrand.

21 NPI (1996) "The Downside of Downsizing: Survive to Thrive", Productivity SA, March/April: 20-2.

22 Roos, P.G. (1992) "Die Invloed van Personeelvermindering op Werknemers wat Hulle Poste Behou", Unpublished Masters dissertation, University of Pretoria.

23 SEGAL, S (1977) "Top Companies. Public Sector Corporations", Supplement to the Financial Mail, June, 27: 352.

24 STEVENSON, M. (1998) "Career Transition Counselling", People Dynamics, October, 16(10): 40-7.

25 SWART, H. (1998) "Staatsdiens se Personeeltal het Met 150000 Gekrimp", Sake-Beeld, April 15, 8.

26 THOMAS, W. (1996) "Downsizing Survivor Syndrome", Proceedings of the 1996 National Occupational Stress Conference: 197-99.

27 VERMEULEN, L P, WIESNER, R and LITTLER, C R. (1999) "Organisational Downsizing and the Survivor Syndrome: Comparative data from South Africa and Australia" Proceedings of the Sixth European Congress of Psychology, July: 462-3.

28 WILLIAMS, F. (1999) "SA in Werkloosheid-Moeras. Geleenthede vir 186000 het Verlore Gegaan", Sake-Beeld. 